\title{
Effect of Varieties and Population of Intercropped Soybean with Maize on Yield and Yield components at Haro Sabu, Western Ethiopia
}

\author{
Teshome Gutu ${ }^{1}$, Tamado Tana ${ }^{2}$ and Negash Geleta ${ }^{3^{*}}$ \\ ${ }^{1}$ Oromia Agriculture Research Institute, Haro Sabu Agricultural Research Center, Ethiopia \\ ${ }^{2}$ College of Agriculture and Environmental Sciences, Haramaya University, Dire Dawa, Ethiopia \\ ${ }^{3}$ Department of Plant Sciences, Wallega University, P.O. Box: 395, Nekemte, Ethiopia
}

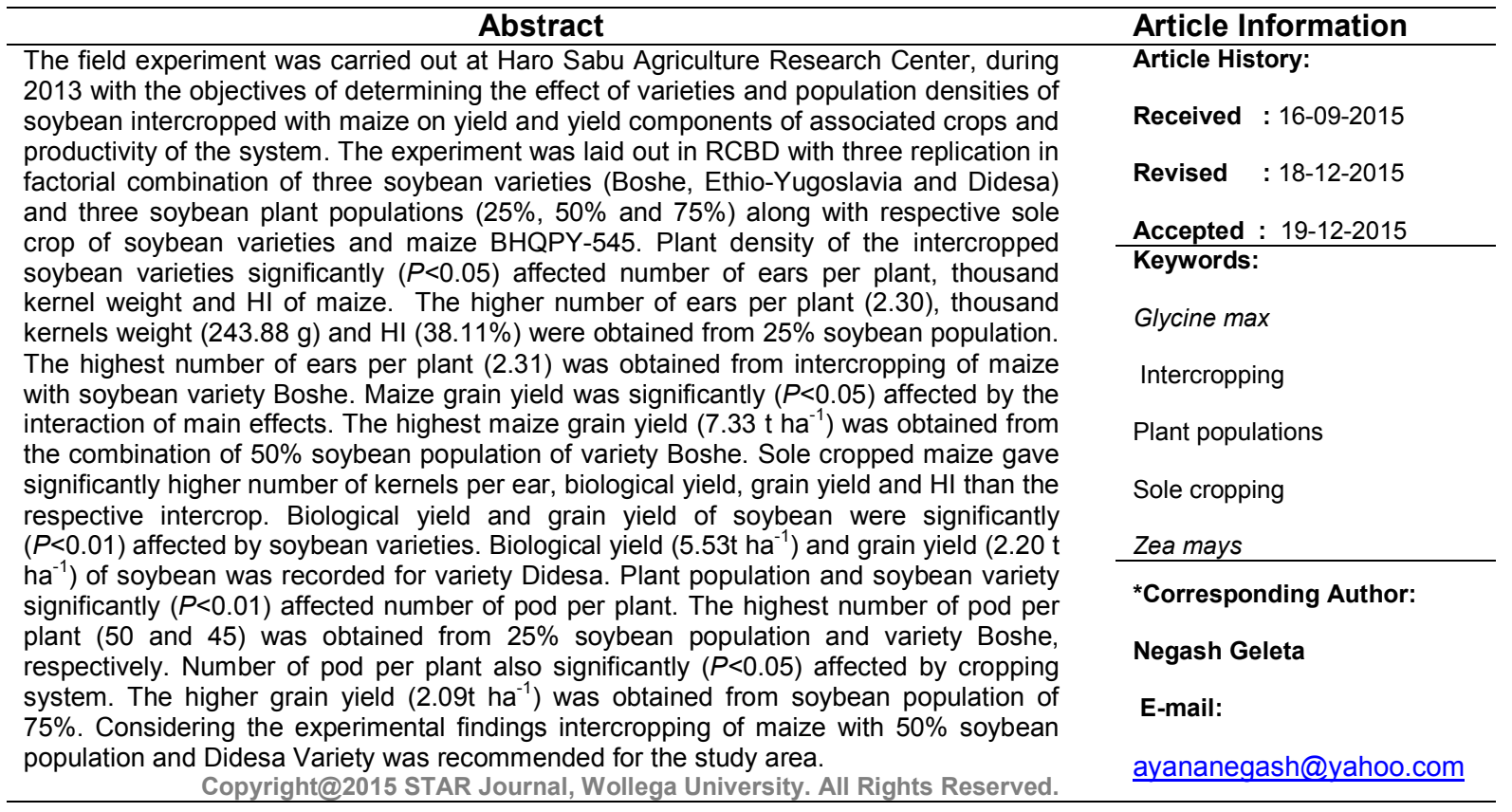

\section{INTRODUCTION}

Intercropping is defined as the growing of more than one crop species more or less simultaneously in the same field during a growing season. It is the practical application of ecological principles such as diversity, crop interaction and other natural regulation mechanisms. The primary objective of all farmers is to sustain production (Barker and Norman, 1975) at reasonable levels and at low risks in order to sustain their needs (Beets, 1990). Most of farmers needs have increased due to the increased population and subsequent reduction in arable land per unit capita. Therefore, the important approach to increase agricultural production is to improve yield of individual crops per unit area at disposal.

Maize (Zea mays L.) is a member of the grass family, Poaceae. It is originated in Central America and was introduced to Ethiopia during the $1600 \mathrm{~s}$ to $1700 \mathrm{~s}$ (Haffangel, 1961). In Ethiopia maize is one of the most important cereal crops grown in the country. From the total area of cereal crop production in 2012/2013 maize took $20.96 \%$ with the production of 61.58 million tones. The total annual production and productivity exceed all other cereal crops, though it is surpassed by tef (Eragrostis tef) in area coverage (CSA, 2013).

The soybean (Glycine max L.) is one of the most important pulses crops of the world, and seems to be growing in importance. It belongs to the family Fabaceae and sub family Papilionaceae and is an annual crop. Historians believe that soybean is one of the oldest crops raised by man. Soybean is known for its wide adaptability coupled with its higher productivity per unit area than other grain legumes. Soybean is useful in crop rotation and intercropping with cereals as its nodules fix atmospheric nitrogen and thus builds up the soil fertility by fixing large amount of atmospheric nitrogen through leaf 
fall on the ground at maturity and optimum rate of $\mathrm{N}$ applied for cereal crop production is less following soybean than following non-leguminous crops (Singh, 1983).

The best cultivar for monocropping might not be most suitable for mixed cropping due to change in microclimate within crop mixture (O'Leary and Smith, 2004). Adeniyan and Ayoola (2006) reported that maturity time and growth habit of component crops were important determinants of productivity in maize soybean intercrops. The overall mixture densities and the relative proportion of component crops are important in determining yields and production efficiencies of cereal-legume intercrop systems (Lakhani, 1976). Ofiri and strern (1987) indicated in a maize/bean intercropping that increasing maize density from 1800 to 5500 plants/ha, reduced leaf area index by $24 \%$ and seed yield by $70 \%$ in the component bean. The intercrops of maize and bean in $100 \%$ of the sole maize population $(44,444$ plants/ha) and $50 \%$ of the sole bean population (125,000 plants/ha) give high yield (Tamado and Eshetu, 2000). Thus, plant population can be used as a tool to manage crop growth, maximize biomass, the time required for canopy closure and yield.

Therefore, planting density, varietal selection, understanding the physiology of the species to be grown together, their growth habits, canopy and root architecture, and water and nutrient use are important factors to be considered in intercropping (Vandermeer, 1989). These factors affect the interaction between the component crops of intercropping and so affect their use of environmental resources and, as a result, the success of intercropping compared with sole cropping systems. However, farmers in western Ethiopia intercrop maize and soybean without consideration of the appropriate densities of the component crops to intercrop. There is lack of information on appropriate variety of soybean for intercropping with maize as all the released soybean varieties were developed under sole cropping. Therefore, intercropping did not give the best returns in terms of yield or cash because farmers do not necessarily select the most compatible varieties and population density for intercropping. Thus the objective of this study was to determine the effect of varieties and population density of soybean intercropped with maize on yield and yield components of the associated crops and productivity of the system.

\section{MATERIALS AND METHODS}

\section{Description of the Study Area}

The study was conducted at Haro Sabu Agricultural Research Center (HSARC) during the main cropping season from June to October 2013. HSARC was located in western Ethiopia in Oromiya region at $550 \mathrm{~km}$ away from Addis Ababa. It lies at latitude of $8^{\circ} 52^{\prime} 51^{\prime \prime} \mathrm{N}$ and longitude $35^{\circ} 13^{\prime} 18^{\prime \prime} \mathrm{E}$ and altitude of $1515 \mathrm{~m}$ above sea level. It has a warm humid climate with average minimum and maximum temperature of 14 and $30^{\circ} \mathrm{C}$, respectively. The area receives average annual rain fall of $1000 \mathrm{~mm}$ and its distribution pattern is uni-modal. The rain periods covers from April to October. The soil type of the experimental site was reddish brown and its $\mathrm{pH}$ is 5.82 . The area were characterized by coffee dominant based farming system and crop-livestock mixed farming system in which cultivation of maize, sorghum, finger millet, haricot bean, soybean, sesame, banana, mango, sweet potato and coffee are the major crops grown in the area.
Improved maize variety (BHQPY-545) was used as main crop and three soybeans varieties namely Boshe, Ethio Yugoslavia and Didesa were used component crop.

\section{Description of the Experimental Materials}

Improved maize variety (BHQPY-545) was used as main crops and adapted to an altitude of $1000 \mathrm{~m}$ to 1800 $\mathrm{m}$ above sea level and matures at 144 days. It requires $1000 \mathrm{~mm}$ to $1200 \mathrm{~mm}$ annual rainfall. Three soybeans varieties namely Boshe, Ethio Yugoslavia and Didesa were used. All the soybean varieties have different maturity date and potential yield and its seeds are yellow in color and adapted to an altitude of $1200-1900 \mathrm{~m}$ above sea level.

\section{Treatments and Experimental Design}

The experiment consisted of two factors, namely three soybean varieties and three soybean plant populations. Three different proportions of a plant population of $333,333 \mathrm{ha}^{-1}$, were considered as optimum for sole cropped soybeans, were taken as the intercrop soybean plant populations: $25 \% \quad\left(83,333\right.$ plants ha $\left.^{-1}\right), 50 \%$ $\left(166,666\right.$ plants ha $\left.{ }^{-1}\right)$ and $75 \%\left(249,999\right.$ plants ha $\left.^{-1}\right)$ were intercropped as additive series between the two maize rows at the same time. Uniform populations of 44,444 plants $\mathrm{ha}^{-1}$ were maintained for maize in both intercropping and sole cropping. The experiment was arranged in Randomized complete Block design with three replication in factorial arrangement of three soybean varieties and three soybean plant populations totaling nine intercropping treatments and there were four additional treatments (sole maize, sole Boshe, sole Ethio-Yugoslavia and sole Didesa) totaling thirteen treatments. The spacing for sole and intercropping maize was $75 \mathrm{~cm} \times 30 \mathrm{~cm}$ between rows plants, respectively and the gross plot size was $15.75 \mathrm{~m}^{2}(3.75 \mathrm{~m} \times 4.2 \mathrm{~m})$ and the net plot area was $6.75 \mathrm{~m}^{2}(2.25 \mathrm{~m} \times 3 \mathrm{~m})$. Each intercrop maize plot consisted of five rows of maize and four row of soybean. The spacing of sole soybean was $60 \mathrm{~cm} \times 5 \mathrm{~cm}$ between rows plants, respectively and the gross plot size $15.12(3.6 \mathrm{~m}$ $\mathrm{x} 4.2 \mathrm{~m})$ and the net plot area was $7.2 \mathrm{~m}^{2}(2.4 \mathrm{~m} \times 3 \mathrm{~m})$. Soybean was intercropped between two maize rows at $37.5 \mathrm{~cm}$ away from maize row with inter row $5.3 \mathrm{~cm}, 8 \mathrm{~cm}$ and $16 \mathrm{~cm}$ representing $75 \%, 50 \%$ and $25 \%$ of the recommended population, respectively. The central three rows of soybean were harvested and one row was used for destructive sampling. i.e for counting number of nodule per plant and for measuring Leaf area \& Leaf area index.

\section{Experimental Procedures}

The experimental field was ploughed and harrowed by a tractor to get a fine seedbed and leveled manually before the field layout was made. Both maize and soybean varieties were planted simultaneously on June 13,2013 . Two seeds per hill of both maize and soybean were planted and thinned to one plant per hill one week after emergence. At planting full dose of DAP $(18 \% \mathrm{~N}$ $46 \% \mathrm{P}_{2} \mathrm{O}_{5}$,) at the rate of $100 \mathrm{~kg} \mathrm{ha}^{-1}$ was applied uniformly into all plots. Half of $\mathrm{N}$ in the form of urea $(46 \%$ $\mathrm{N})$ at the rate of $200 \mathrm{~kg} \mathrm{ha}^{-1}$ was applied into sole maize and maize/soybean intercropped plots at the time of planting and the remaining half $\mathrm{N}$ was applied at knee height growth stage of maize. Urea $(\mathrm{N})$ was not applied in to sole soybean assuming the soybean could benefit from self-fixed nitrogen. Hand hoeing and weeding were done as required. Both maize and soybean were harvested from the net plot after they attained their normal physiological maturity, i.e. when $75 \%$ of plants in a plot 
formed black layer at the point of attachment of the kernel with the cob for maize and when $95 \%$ of pod color changed to yellow and their leaves started shading for soybean and the both maize and soybean were threshed manually.

\section{Soil Sampling and Analysis}

Soil sample was taken at a depth of $0-30 \mathrm{~cm}$ in a zigzag pattern randomly from the experimental field. Composite samples were prepared for analysis to determine the physico-chemical properties of the soil of the experimental site. The composited soil sample was air-dried, ground and sieved to pass through a $2 \mathrm{~mm}$ sieve. Total nitrogen was determined following kjeldahl procedure as described by (Cottenie, 1980); the soil pH was determined by using a digital $\mathrm{pH}$ meter (Page, 1982). Organic carbon was determined following wet digestion method as described by (Walkley and Black, 1934); and the available phosphorous was measured using Olson II methods (Olsen et al., 1954); cation exchange capacity (CEC) was determined by ammonium acetate method (Cottenie, 1980)and soil texture was determined by Bouyoucons Hydrometer method (Bouyoucos, 1962).

\section{Statistical Data Analysis}

Analysis of variance was carried out using General Linear Model of ANOVA using SAS version 9.0 software (SAS Institute Inc. 2002). Mean separation was carried out using Least Significance Difference (LSD) test at 5\% probability level.

\section{RESULTS AND DISCUSSION}

\section{Physicochemical Properties of the Soil}

Result of the laboratory analysis for the soil samples taken before planting of the experimental site is indicated in Table 1. The analysis indicate that the soil had total nitrogen content of $0.436 \%$ which was high according to Tekaligne et al. (1991) where they classified soil total $\mathrm{N}$ availability of $<0.05 \%$ as very low, $0.05-0.12 \%$ as poor, $0.12-0.25 \%$ as moderate and $>0.25 \%$ as high. Where organic matter content of the soil $(4.715 \%)$ is medium according to the classification of Berhanu (1980) where soils with organic matter content of $>5.20,2.6-5.2,0.8-2.6$ and $<0.8 \%$ were classified as high, medium, low and very low, respectively, in their organic matter status.

With regards to the available phosphorus, Tekalign et al. (1991) described soils with available $P<10,11-31$, 3256 , >56ppm as low, medium, high and very high, respectively. Thus, the soil available $P(6.283 \mathrm{ppm})$ content of experimental sites was low. The soil cation exchange capacity describes the potential fertility of soils and is an indicator of the soil texture, organic matter content and the dominant types of clay minerals present. In general, soils high in CEC contents are considered as agriculturally fertile. According to Landon (1991), top soils having CEC greater than $40 \mathrm{Cmol}(+) / \mathrm{kg}$ are rated as very high and 25-40 $\mathrm{Cmol}(+) / \mathrm{kg}$ as high, 15-25, 5-15 and $<5$ $\mathrm{Cmol}(+) / \mathrm{kg}$ of soil are classified as medium, low and very low, respectively in CEC. Thus, the CEC of the 23 $\mathrm{Cmol}(+) / \mathrm{kg}$ is rated as medium.

The analytical results indicated that the textural class of the experimental site was mainly of sandy loam soil with a proportion of $73 \%$ sand, $6 \%$ clay and $21 \%$ silt. Thus, the textural class of the experimental soil is ideal for maize production (Onwueme and Sinha, 1991). The soil reaction $(\mathrm{pH})$ of the experimental site was 5.82 showing moderate acidity, but it is within the optimum range for maize production, i.e. $5.5-7.0$.

Table 1: Physico-chemical properties of experimental soil before planting

\begin{tabular}{lc}
\hline Soil characteristic & Value \\
\hline Particle size (\%) & \\
Sand & 73 \\
Silt & 21 \\
Clay & 6 \\
Textural class & Sandy loam \\
pH $\left(1: 2.5 \mathrm{H}_{2} \mathrm{O}\right)$ & 5.82 \\
Organic matter $(\%)$ & $4.715(\%)$ \\
Total nitrogen $(\%)$ & 0.436 \\
Available phosphorous $(\mathrm{ppm})$ & 6.283 \\
Cation exchange capacity $(\mathrm{Cmol}(+) / \mathrm{kg})$ & $23 \mathrm{Cmol}(+) / \mathrm{kg}$ \\
\hline
\end{tabular}

Maize Component

Yield and Yield Components

Analysis of variance indicated no significant effects of varieties, plant population of the intercropped soybean and their interaction on stand count of maize at harvest. Moreover, there was no significant difference between the sole and intercropped maize on stand count at harvest, but sole cropped maize had slightly higher stand count (43950 $\mathrm{ha}^{-1}$ ) than intercropped maize (43566.10 ha $\left.{ }^{-1}\right)$ (Table 2). The decrease in number of maize plants under intercropping might be due to self-thinning as a result of competition between the two crops for growth resources.

The main effect of variety and plant population of the intercropped soybean and their interaction showed no significant effect on maize above ground dry biomass. However, the highest aboveground maize biomass yield of 19.11 and $19.00 \mathrm{t} \mathrm{ha}^{-1}$ were obtained from the intercropped soybean population of $25 \%$ and in association with soybean variety Boshe, respectively (Table 2). The highest biomass recorded for maize intercropped with soybean at $25 \%$ planting density might be due to less planting density that might have resulted in less competition between maize. Likewise, the highest biomass recorded for maize intercropped with variety Boshe might be due to the early maturity of the variety that provided temporal complimentarily of the soybean as compared to other varieties which were late maturing. In agreement with this result, Carr et al. (1992) reported that sorghum produced comparable amount of stover whether it was monocropped or intercropped with low or moderate bean population. Similarly, Zerihun (2011) reported no significant difference on dry biomass of the intercropped maize due to the associated soybean varieties.

On the other hand, cropping system had highly significantly $(P<0.01)$ effect on maize biomass where significantly higher biomass of maize $\left(19.00 \mathrm{t} \mathrm{ha}^{-1}\right)$ was produced from sole cropped maize than that of intercropped maize with soybean (18.67 tha $\mathrm{th}^{-1}$ ) (Table 2). The lower biomass yield produced from intercropped maize might be due to inter specific competition between component crops. In line with this result, Shehu et al. (1999) reported significantly higher sorghum stalk yield for sole crop compared with different mixed cropping treatments. Likewise, Luiz and Robert (2003) reported that intercropping as compared with sole cropping decreased biomass yield of maize under intercropping with common bean. Also Biruk (2007) reported higher biomass of sorghum from sole cropped sorghum than sorghum intercropped with bean. 
Number of kernels per ear was not significantly affected by variety and plant population of the intercropped soybean. However; cropping systems had significant $(P<0.05)$ effect on number of kernels per ear where significantly higher number of kernels per ear (456.00) was obtained from sole cropped maize than the intercropped maize (440.67) with soybean (Table 2). More number of kernels set per ear might be probably related to greater dry matter partitioning to the ear and to more number of kernels set per unit dry matter allocated to the ear during the critical period for kernel set (Echarte et al., 2000).

Table 2: Main effects of varieties and plant populations of the intercropped soybean and cropping system on stand count, above ground dry biomass and number of kernels per ear of the maize component

\begin{tabular}{|c|c|c|c|}
\hline Treatment & $\begin{array}{c}\text { Stand count } \\
\mathrm{ha}^{-1}\end{array}$ & $\begin{array}{l}\text { Total biological } \\
\left.\text { Yield (t ha }{ }^{-1}\right)\end{array}$ & $\begin{array}{l}\text { Number of } \\
\text { kernels } \\
\text { per ear }\end{array}$ \\
\hline \multicolumn{4}{|l|}{ Soybean population per ha } \\
\hline $75 \%(249,999)$ & 43456.2 & 18.77 & 439.78 \\
\hline $50 \%(166,666)$ & 43950.1 & 18.66 & 439.67 \\
\hline $25 \%(83,333)$ & 43291.7 & 19.11 & 442.67 \\
\hline LSD $(0.05)$ & NS & NS & NS \\
\hline \multicolumn{4}{|l|}{ Soybean varieties } \\
\hline Boshe & 43785.60 & 19.00 & 445.22 \\
\hline Didesa & 43291.70 & 18.89 & 442.89 \\
\hline Ethio Yugoslavia & 43620.80 & 18.67 & 434.00 \\
\hline LSD (0.05) & NS & NS & NS \\
\hline CV $(\%)$ & 2.99 & 4.94 & 4.09 \\
\hline \multicolumn{4}{|l|}{ Cropping system } \\
\hline Sole & 43950.00 & $19.00 a$ & $456.00 a$ \\
\hline Intercropping & 43566.10 & $18.67 \mathrm{~b}$ & $440.67 b$ \\
\hline LSD (0.05) & NS & 0.09 & 7.79 \\
\hline $\mathrm{CV}(\%)$ & 1.48 & 0.21 & 0.76 \\
\hline
\end{tabular}

Means within the same column followed by the same letter or by no letters of each factor do not differ significantly at $5 \%$ probability level; LSD $=$ Least Significant Difference $(P<0.05) ; C V=$ Coefficient of Variation; NS =Non Significant

The main effects of plant population showed significant $(P<0.05)$ effect on number of ears per plant. The highest number of ears per plant (2.30) was obtained from maize intercropped with $25 \%$ of soybean population while the lowest number of ears per plant (1.95) was obtained from maize intercropped with $75 \%$ of soybean population (Table 3). This might be due to increased inter competition for growth resources from the associated soybean as its density increased.

The main effects of plant population showed significant $(P<0.05)$ effect on thousand kernel weight. The highest thousand kernel weight $(243.88 \mathrm{~g})$ was obtained from maize intercropped with $25 \%$ of soybean population while intercropping with $75 \%$ soybean population gave the lowest thousand kernel weight (229.11g) (Table 3). In conformity with this result, Biruk (2007) reported that $25 \%$ common bean: $100 \%$ sorghum planting density gave the highest mean 1000 kernel weight of the sorghum component. In contrast, Tilahuun (2002) and Tolera (2003) reported that planting density of beans had no significant effect on 1000 kernel weight of the associated maize.

The differences in weight per grain observed at different plant densities might result from differences in the initial size of the kernels in growth rates during the exponential and linear (starch deposition) phases of grain growth or in the duration of those phases (Jones and Simmons, 1986). Lemcoff and Loomis (1986) observed that the initial grain weight after pollination was a key factor in the early growth of the kernel. Thus, at high plant density, the kernel weight was smaller which could in turn be due to delay in development (later initiation of kernels) or smaller initial size of the kernels primordial. The final kernel weight correlates strongly with the numbers of cells and starch granules formed, particularly in the endosperm tissue, representing about $85 \%$ of the weight of mature maize kernels. Therefore, under high plant density, yield may be restricted by limitations in the capacity for endosperm growth either by number, size or activity of endosperm cells (Salvador and Perarce, 1995). There is also an interaction between kernel position and number in terms of competition for substrates required for growth, which is more accentuated at high plant density.

The main effect of soybean varieties was significant $(P<0.05)$ on number of ear per plant but non-significant on thousand kernel weight. The highest number of ears per plant (2.31) of the maize component was obtained in association with soybean variety Boshe while the lowest number of ears per plant (1.95) was obtained in association with soybean variety Ethio Yugoslavia (Table $3)$. The reduction in number of ears per plant in association with variety Ethio Yugoslavia might be due to high vegetative growth of the variety, i.e. high LA (2799.80 $\mathrm{cm}^{2}$ ), plant height $(123.89 \mathrm{~cm})$ and late maturity $(141.55$ days) that might have caused intense competition and reduction in the ear leaf photosynthesis of maize due to inter specific competition.

Number of ears per plant showed significant $(P<0.05)$ difference due to cropping systems. However, thousand kernel weight of maize was not significantly affected by cropping system. Significantly higher number of ears per plant (2.33) was recorded from sole maize than the intercropped maize (2.10) (Table 3). The reduction in number of ears per plant in intercropped maize might be due to the reduction in the ear leaf photosynthesis due to competition for growth resources with soybean.

The main effects of plant population and cropping system showed significant $(P<0.05)$ effect on harvest index while the effect of soybean varieties was not 
Teshome Gutu et al.,

significant $(P<0.05)$. The highest harvest index of maize $(38.11 \%)$ was recorded from intercropping of maize with $25 \%$ of soybean population whereas the lowest $\mathrm{HI}$ $(36.22 \%)$ was recorded from intercropping of maize with $75 \%$ of soybean population (Table 3 ).

Significantly higher $\mathrm{HI}$ of maize $(38.66 \%)$ was obtained from sole maize that the intercropped maize $(37.43 \%)$ (Table 3). Lower $\mathrm{HI}$ of maize under intercropping might be
Sci. Technol. Arts Res. J., Oct-Dec 2015, 4(4): 31-39

due to inter specific competition for growth resources, i.e. moisture, nutrients and light. The present result agreed with that reported by Zerihun (2011) where higher $\mathrm{HI}$ $(44.7 \%)$ of maize was recorded from sole maize than intercropped maize $(41.5 \%)$ with soybean varieties. Similarly, Karikari et al. (1999) in Bambara groundnut + maize and Bambara groundnut + sorghum intercropping, reported significantly higher harvest indices for sole maize (0.599) and sole sorghum (0.386) than those in intercrops.

Table 3: Main effects of varieties and plant population of the intercropped soybean and cropping system on number of ears, 1000 kernel weight and harvest index of the maize component

\begin{tabular}{lccc}
\hline \multicolumn{1}{c}{ Treatment } & $\begin{array}{c}\text { Number of } \\
\text { ear plant }^{-1}\end{array}$ & $\begin{array}{c}\text { Thousand } \\
\text { kernel weight (g) }\end{array}$ & $\begin{array}{c}\text { Harvest } \\
\text { index (\%) }\end{array}$ \\
\hline Soybean population per ha & & & \\
$75 \%(249,999)$ & $1.95^{\mathrm{b}}$ & $229.11^{\mathrm{c}}$ & $36.22^{\mathrm{b}}$ \\
$50 \%(166,666)$ & $2.14 \mathrm{a}^{\mathrm{b}}$ & $239.88^{\mathrm{ab}}$ & $37.66^{\mathrm{ab}}$ \\
$25 \%(83,333)$ & $2.30^{\mathrm{a}}$ & $243.88^{\mathrm{a}}$ & $38.11^{\mathrm{a}}$ \\
LSD (0.05) & 0.22 & 11.52 & 1.45 \\
\hline Soybean varieties & & & \\
Boshe & $2.31^{\mathrm{a}}$ & 240.55 & 37.66 \\
Didesa & $2.13^{\mathrm{ab}}$ & 242.00 & 37.44 \\
Ethio Yugoslavia & $1.95^{\mathrm{c}}$ & 230.33 & 36.88 \\
LSD (0.05) & 0.18 & & \\
CV (\%) & 10.74 & 4.85 & 3.89 \\
\hline Cropping system & & & \\
Sole & $2.33^{\mathrm{a}}$ & 238.33 & $38.66 \mathrm{a}$ \\
Intercropping & $2.10^{\mathrm{b}}$ & 237.60 & $37.43 \mathrm{~b}$ \\
LSD (0.05) & 0.18 & & 0.93 \\
CV (\%) & 3.68 & 1.48 & 1.07 \\
\hline
\end{tabular}

Means within the same column followed by the same letter or by no letters of each factor do not differ significantly at $5 \%$ probability level; LSD = Least Significant Difference $(P<0.05) ; C V=$ Coefficient of Variation; NS =Non Significant

The main effects of plant populations and varieties showed highly significant $(P<0.01)$ effects on grain yield of the maize component also their interaction effect showed significant at $(P<0.05)$. The highest maize yield $(7.33 \mathrm{t} \mathrm{ha}$ ${ }^{1}$ ) was obtained from the combinations of $100 \%$ maize $x$ $50 \%$ plant population of soybean variety Boshe while the lowest grain yield $\left(6.80 \mathrm{t} \mathrm{ha}^{-1}\right)$ was obtained from combination of $100 \%$ maize $\times 75 \%$ plant population of soybean variety Ethio-Yugoslavia (Table 4). The highest grain yield of maize from $50 \%$ population of soybean variety Boshe might be due to reduction in competition for growth resources due to its early maturity of the intercropped variety. This result was in conformity with that of Rao (1980) who reported that early maturing legume varieties could lead to increased productivity of the cereal component. The yield reduction due to $75 \%$ population of variety Ethio Yugoslavia might be due to its late maturity (141.55 days) which was almost same with the maize component. In line with this result, Davis and Garcia (1983) reported that maize yield was reduced by $17 \%$ when intercropped with the most competitive common bean cultivars.

Sole cropped maize had significantly higher grain yield $\left(7.33 \mathrm{t} \mathrm{ha}^{-1}\right)$ than the intercropped system $\left(7.01 \mathrm{t} \mathrm{ha}^{-1}\right)$. The grain yield reduction of the intercropped maize might be associated with inter specific competition between the intercrop components for growth resources (light, water, nutrients etc.) and depressive effects of soybean on maize at early growth stage because both crop were planted simultaneously and soybean was emerged earlier than maize. In accordance with this result, Shehu et al. (1999), Tamado and Eshetu (2000), Yesuf (2003) and Dechasa (2005) reported that yield of sole cropped sorghum was significantly higher than intercropped sorghum.

Table 4: Interaction effect of the intercropped soybean varieties and plant populations on grain yield (ton ha ${ }^{-1}$ ) of maize in maize/soybean intercropping

\begin{tabular}{|c|c|c|c|}
\hline \multirow{2}{*}{$\begin{array}{c}\text { Soybean Population } \\
\text { per ha }\end{array}$} & \multicolumn{3}{|c|}{ Soybean varieties } \\
\hline & Boshe & Didesa & Ethio-Yugoslavia \\
\hline $75 \%(249,999)$ & $7.00^{\mathrm{bc}}$ & $6.90^{\mathrm{cd}}$ & $6.80^{\mathrm{d}}$ \\
\hline $50 \%(166,666)$ & $7.33^{\mathrm{a}}$ & $7.10^{\mathrm{b}}$ & $6.90^{\mathrm{cd}}$ \\
\hline $25 \%(83,333)$ & $7.00^{\mathrm{bc}}$ & $7.10^{\mathrm{b}}$ & $7.00^{\mathrm{bc}}$ \\
\hline Intercropping mean & \multirow{2}{*}{\multicolumn{2}{|c|}{$\begin{array}{l}7.01^{\mathrm{b}} \\
7.33^{\mathrm{a}}\end{array}$}} & \\
\hline Sole mean & & & \\
\hline $\begin{array}{l}\text { LSD (0.05) } \\
\text { CV (\%) }\end{array}$ & \multicolumn{2}{|c|}{$\begin{array}{c}\text { Soybean variety } \mathrm{x} \text { population } \\
0.18 \\
1.52\end{array}$} & $\begin{array}{c}\text { Cropping system } \\
0.28 \\
1.11\end{array}$ \\
\hline
\end{tabular}

$5 \%$ probability level; LSD $=$ Least Significant Difference $(P<0.05) ; C V=$ Coefficient of variation 


\section{Soybean Component}

\section{Yield and Yield Component}

The analysis of variance showed that number of pod per plant was highly significantly $(P<0.01)$ affected by main effect of plant population and soybean varieties. It was significantly $(P<0.05)$ affected by cropping system but not significantly affected by the interaction. The highest number of pod per plant (50.00) was recorded from $25 \%$ soybean population while the lowest number of pods per plant (26.56) was obtained from $75 \%$ soybean population (Table 5). With regards to variety, the highest number of pods per plant (45) was obtained for variety Boshe while variety Ethio-Yugoslavia had the lowest (31.89) (Table 5 ). The decrease in number of pods per plant at higher plant density might be due to increased inter and intraspecific competition for growth resources, which might have lead to reduced number of effective branches. The higher pod per plant at $25 \%$ soybean population might also be due to the lower soybean population and the lower maize competition due to the greater distance between soybean plants that might have provided a better soil resource condition with higher light availability for soybean plants. This result was in agreement with Biruk (2007) who reported in sorghum/common bean intercropping the number of pods per plant decreased with the increase in planting density. Similarly, Luiz and Robert (2003) reported that increasing bean population in maize/bean intercropping, significantly decreased the number of pods per bean plant. Significantly higher number of pods per soybean plant (37.92) was obtained from intercropped than sole cropped soybean (30.00) (Table 5). This is might be due lower intra spaces competition for growth resources due to more wide interrow $(75 \mathrm{~cm})$ between soybean plants and row when compared to sole soybean and it might also be due to the fact that inter cropped soybean plants get additional $\mathrm{N}$ fertilizer from the applied $\mathrm{N}$ fertilizer for maize.

Number of seeds per pod was not significantly affected by main effect of plant population, soybean varieties, interaction and cropping system. This result was in agreement with Sisay (2004) on sorghum/green gram intercropping and with Dechasa (2005) on sorghum/bean intercropping where planting density had non-significant effect on number of seeds per pod of the legume components.

Hundred seed weight of the associated soybean was not significantly affected by main effect of plant population and interaction and cropping system, but was significantly $(P<0.01)$ affected by soybean variety. The highest hundred seed weight $(20.67 \mathrm{~g})$ was recorded for variety Didesa while the lowest seed weight was recorded for variety Boshe $(17.11 \mathrm{~g})$ (Table 5 ). The variation in seed weight for varieties could be due to the fact that seed size is a genetic trait hence it did not change much with change in plant population or cropping system. This result was in agreement with the result reported by Biruk (2007) here hundred seed weight was significantly $(P<0.05)$ different between common bean varieties under sorghum/common bean and maize/ common bean intercropping respectively. Similarly, Zerihun (2011) reported that thousand seed weight of soybean was significantly $(P<0.05)$ different under maize/soybean intercropping due to soybean variety.

The aboveground dry biomass of the soybean component showed a highly significant $(P<0.01)$ variation among varieties and plant population and cropping system, while the interaction effect was not significant. Among the varieties, the highest aboveground dry biomass was obtained for variety Didesa $\left(5.53 \mathrm{t} \mathrm{ha}^{-1}\right)$ while the lowest biomass yield was for variety Ethio Yugoslavia (4.44 $\mathrm{t} \mathrm{ha}^{-1}$ ). The lower aboveground dry biomass yield for variety Ethio Yugoslavia might be due to lower number of branches and pods per plants (Table 5). Variety Didesa produced significantly more aboveground dry biomass yield than the other varieties which might be due to higher competitive ability with maize and probably because of higher nodule formations that met its nitrogen requirement. Similarly, Zerihun (2011) reported that variety Didesa produced more biological yield than variety Boshe. The lowest aboveground dry biomass of the soybean $\left(4.10 \mathrm{t} \mathrm{ha}^{-1}\right)$ was obtained from $25 \%$ soybean population. The decreased biomass yield of soybean at decreased plant population might be due to less soybean plant population. In accordance with this result, Biruk (2007) and Luiz and Robert (2003) reported that biological yield of bean increased as plant population increased under sorghum and maize/bean intercropping, respectively.

Cropping system also had highly significant $(P<0.01)$ effect on aboveground dry biomass of the soybean. Significantly higher biomass yield $\left(9.15 \mathrm{t} \mathrm{ha}^{-1}\right)$ was recorded from sole cropped soybean than the intercropped soybean (5.01 $\left.\mathrm{t} \mathrm{ha}^{-1}\right)$ (Table 5). The decreased biomass production in intercropping might be due to the shading effect of maize that might have reduced light requirement of the intercropped soybean and consequently resulted in reduced biomass accumulation. Moreover, higher biomass yield in sole cropped soybean might be due to more number of plants per unit area under sole cropping than in intercropping. This result was in conformity with the result reported by Chui and Shibles (2003) where intercropping reduced soybean biological yield by $87 \%$ when compared with sole cropping, principally because of reduced plant growth and photosynthetic assimilation (Kipkemoi et al., 2003).

Analysis of variance showed a significant $(P<0.01)$ variation in grain yield due to the effect of associated varieties, plant population and cropping system, while the interaction effect was not significant. The highest yield $\left(2.20 \mathrm{t} \mathrm{ha}^{-1}\right)$ was obtained from the intercropped variety Didesa followed by Boshe $\left(1.80 \mathrm{t} \mathrm{ha}^{-1}\right)$ while variety Ethio Yugoslavia gave the lowest grain yield $\left(1.67 \mathrm{t} \mathrm{ha}^{-1}\right)$ (Table $5)$. The highest grain yield for variety Didessa could be due to higher yielding potential as it had the highest aboveground dry biomass and hundred grains weight. Similarly, Egbe (2010) reported such significant yield differences among varieties of soybean in intercropping system. Likewise, Zerihun (2011) reported that intercropping of Didesa variety with maize resulted in significant yield increase over Boshe and this increase in yield was about $57.7 \%$.

With regards to plant population, the highest grain yield $\left(2.09 \mathrm{t} \mathrm{ha}^{-1}\right)$ was recorded from soybean population of $75 \%$ followed by $50 \%$ soybean population $\left(2.06 \mathrm{t} \mathrm{ha}^{-1}\right)$ and the lowest from $25 \%$ soybean population $\left(1.52 \mathrm{t} \mathrm{ha}^{-1}\right)$ (Table 5). Grain yield increased with the increase in plant population of soybean which could be the result of more plant established under the intercropping system. In conformity with this result, Akunda (2001) demonstrated that higher soybean populations provided a way to 
Teshome Gutu et al.,

optimizing yields in soybean/millet intercropping systems. Similarly, Biruk (2007) reported that seed yield of intercropped common bean with sorghum was increased with the increase in plant density of the soybean component.

Because of additive intercropping of maize and soybean, the yield of intercropped soybean was reduced by $47.5 \%$ as compared to sole cropped soybean. Higher grain yield $\left(3.60 \mathrm{t} \mathrm{ha}^{-1}\right)$ was obtained from sole cropped soybean than the intercropped soybean (1.89 $\left.\mathrm{t} \mathrm{ha}^{-1}\right)$ (Table 5). Lower grain yield of intercropped soybean might be due to increase inter-specific competition and lower soybean plant population in intercropping than sole
Sci. Technol. Arts Res. J., Oct-Dec 2015, 4(4): 31-39

cropping. Muoneke et al. (2007) reported similar yield reduction in soybean inter cropped with maize and sorghum and attributed the yield depression to inter specific competition and the depressive effect of the cereals. Ghosh (2004) further explained that because of the difference in canopy height of soybean and sorghum, the two species not only competed for nutrient and water but also for light. The shading effect of the maize drastically reduced the light transmission that might have significantly reduced photosynthetic assimilates. A range of $21 \%$ to $75 \%$ yield reduction of the intercropped soybean due to shading effect was reported by Kipkemoi et al. (2003) and Mudita et al. (2008).

Table 5: Main effects of varieties and plant population of the intercropped soybean with maize on yield components and yield of the soybean component

\begin{tabular}{|c|c|c|c|c|c|}
\hline Treatment & NPPP & NSPP & HGW (g) & BY $\left(\mathrm{t} \mathrm{ha}^{-1}\right)$ & GY $\left(t^{h a} a^{-1}\right)$ \\
\hline \multicolumn{6}{|c|}{ Soybean population per ha } \\
\hline $75 \%(249,999)$ & $26.56^{c}$ & 2.00 & 20.30 & $5.31^{a}$ & $2.09^{a}$ \\
\hline $50 \%(166,666)$ & $37.44^{\mathrm{b}}$ & 2.01 & 18.55 & $5.47^{\mathrm{a}}$ & $2.06^{\mathrm{a}}$ \\
\hline $25 \%(83,333)$ & $50.00^{\mathrm{a}}$ & 2.03 & 18.00 & $4.10^{\mathrm{b}}$ & $1.52^{\mathrm{b}}$ \\
\hline LSD (0.05) & 6.50 & NS & NS & 0.54 & 0.22 \\
\hline \multicolumn{6}{|l|}{ Soybean varieties } \\
\hline Boshe & $45.00^{a}$ & 2.01 & $17.11^{\mathrm{b}}$ & $4.90^{\mathrm{b}}$ & $1.80^{\mathrm{b}}$ \\
\hline Didesa & $37.11^{\mathrm{b}}$ & 2.02 & $20.6^{7 a}$ & $5.53^{a}$ & $2.20^{a}$ \\
\hline Ethio Yugoslavia & $31.89^{\mathrm{b}}$ & 2.01 & $19.11^{\mathrm{ab}}$ & $4.44^{\mathrm{b}}$ & $1.67^{\mathrm{b}}$ \\
\hline $\begin{array}{l}\text { LSD (0.05) } \\
\text { CV (\%) }\end{array}$ & $\begin{array}{c}6.50 \\
17.12\end{array}$ & $\begin{array}{l}\text { NS } \\
1.72\end{array}$ & $\begin{array}{c}2.15 \\
11.38\end{array}$ & $\begin{array}{c}0.54 \\
11.04\end{array}$ & $\begin{array}{c}0.22 \\
12.13\end{array}$ \\
\hline \multicolumn{6}{|l|}{ Cropping system } \\
\hline Sole & $30.00^{\mathrm{b}}$ & 2.00 & 17.88 & $9.15^{\mathrm{a}}$ & $3.60^{a}$ \\
\hline Intercropping & $37.92^{a}$ & 2.01 & 19.04 & $5.01^{\mathrm{b}}$ & $1.89^{b}$ \\
\hline LSD (0.05) & 5.41 & NS & NS & 1.05 & 0.49 \\
\hline CV $(\%)$ & 4.53 & 0.20 & 6.25 & 4.23 & 5.07 \\
\hline
\end{tabular}

Means within the same column followed by the same letter or by no letters of each factor do not differ significantly at $5 \%$ probability level; LSD = Least Significant Difference $(P<0.05) ; C V=$ Coefficient of Variation; NS =Non Significant;

NPPP= Number of pod per plant; NSPP= Number of seed per pod; HGW= Hander grain weight; GY= grain yield

Harvest index of soybean was highly significantly $(P<0.01)$ affected by variety and plant population and their interaction while cropping system did not show significant effect. The highest soybean harvest index $(42.67 \%)$ was obtained from $75 \%$ soybean population of variety Didesa and the lowest soybean harvest index $(36.67 \%)$ was obtained from $25 \%$ population of variety Boshe (Table
6).The highest Harvest index recorded for variety Didesa intercropped with maize might be due to the high grain yield to biomass obtained by the variety as a result of high partitioning of dry matter to the grain. This result was in agreement with Zerihun (2011) who reported that $43 \%$ of Harvest index was recorded from intercropped Didesa variety with maize.

Table 6: The interaction effect of varieties and plant population of the intercropped soybean with maize on harvest index (\%) of the soybean component

\begin{tabular}{|c|c|c|c|}
\hline \multirow{2}{*}{$\begin{array}{c}\text { Soybean population } \\
\text { per ha }\end{array}$} & \multicolumn{3}{|c|}{ Soybean varieties } \\
\hline & Boshe & Didesa & Ethio Yugoslavia \\
\hline $75 \%(249,999)$ & $37.00 \mathrm{~b}$ & $42.67 a$ & $37.67 \mathrm{~b}$ \\
\hline $50 \%(166,666)$ & $37.00 \mathrm{~b}$ & $38.00 b$ & $38.00 \mathrm{~b}$ \\
\hline $25 \%(83,333)$ & $36.67 \mathrm{~b}$ & $38.00 \mathrm{~b}$ & $38.00 \mathrm{~b}$ \\
\hline Intercropping mean & \multirow{2}{*}{\multicolumn{2}{|c|}{$\begin{array}{c}38.11 \\
39.33\end{array}$}} & \\
\hline Sole mean & & & \\
\hline $\begin{array}{l}\text { LSD (0.05) } \\
\text { CV (\%) }\end{array}$ & \multicolumn{2}{|c|}{$\begin{array}{c}\text { Soybean variety } x \text { population } \\
1.60 \\
2.47\end{array}$} & $\begin{array}{l}\text { Cropping system } \\
\text { NS } \\
1.07\end{array}$ \\
\hline
\end{tabular}

Means within the column and rows followed by the same letter do not differ significantly at $5 \%$ probability level; LSD = Least Significant Difference; CV = Coefficient of Variation

\section{CONCLUSIONS}

The main effects of plant population showed significant effect on number of ears per plant and thousand kernel weight. The main effects of plant populations and varieties showed highly significant effects on grain yield of the maize component. The highest maize yield was obtained from the combinations of $100 \%$ maize $\times 50 \%$ plant population of soybean variety Boshe. Number of pod per plant was highly significantly affected by main effect of plant population and soybean varieties. It was significantly affected by cropping system but not significantly affected by the interaction. The highest number of pod per plant 
Teshome Gutu et al.,

was recorded from $25 \%$ soybean population while the lowest number of pods per plant was obtained from $75 \%$ soybean population. With regards to variety, the highest number of pods per plant was obtained for variety Boshe while variety Ethio-Yugoslavia had the lowest. Significantly higher number of pods per soybean plant was obtained from intercropped than sole cropped soybean. Hundred seed weight was significantly $(P<0.01)$ affected by soybean variety. The highest hundred seed weight was recorded for variety Didesa while the lowest seed weight was recorded for variety Boshe. Grain yield of soybean was significantly affected by associated varieties, plant population and cropping system. The highest grain yield was obtained from the intercropped variety Didesa. Considering the experimental findings intercropping of maize with $50 \%$ soybean population and Didesa Variety was recommended for the study area.

\section{Conflict of Interest}

Conflict of Interest none declared.

\section{REFERENCES}

Adeniyan, O.N.' Ayola O.T. (2006). Growth and yield performance of some improved Soybean varieties as influenced by intercropping with maize and cassava in South West Nigeria. African Journal of Biotechnology 5(20):1886-1889.

Akunda EM. (2001). Intercropping and population density effects on yield component, seed quality and photosynthesis of sorghum and soybean. Journal of Food Technology (Africa) 6: 170-172.

Barker, E.F.I and Norman, D.W., 1975. Cropping system in north Nigeria. IAR, samuru, Nigeria.

Beets, C.W. (1990). Raising and sustaining productivity of small holder farming systems in the tropics. AgBe publishing, Singapore.

Berhanu Debele (1980). The physical criteria and their rating proposed for land evaluation in the highland region of Ethiopia. Land use planning and regulatory department, Ministry of Agriculture. Addis Ababa, Ethiopia.

Biruk Tesfaye (2007). Effect of planting density and varity of common bean (Phaseolus vulgaris L.) intercropped with sorghum (Sorghum bicolor L.) on performance of the component crops and productivity of the system in South Gonder, Ethiopia. M.Sc. Thesis Haramaya University, Ethiopia.

Bouyoucos, G.J. (1962). Hydrometer method improved for making particle size analysis. Agronomy Journal 54: 464465.

Carr, P.M., Schatz, B.G., Gardner, J.C., Zwinger, S.F. (1992). Intercropping sorghum and pinto bean in a cool semiarid region. Agronomy Journal 84: 810-812.

Chui, A.N, Richard S. (2003). Influence of spatial arrangements of maize on performance of an associated soybean intercrop. Journal Paper No. J-10887 of the lowa Agriculture and Home Economics Experimental Station. Ames. IA 50011 (U.S.A.)

Cottenie, A. (1980). Soil and plant testing as a basis for fertilizer recommendations. FAO Soil Bulletin, Rome 38: $61-100$

CSA (Central Statistical Agency) (2013). The Federal Democratic Republic of Ethiopia Central Statistical Agency, Agricultural Sample Survey. Volume I, Report on
Sci. Technol. Arts Res. J., Oct-Dec 2015, 4(4): 31-39

Area and Production of Major Crops (Private Peasant Holdings, Meher Season), Addis Ababa, Ethiopia.

Davis, J.H.C., Garcia, S. (1983). Competitive ability and growth habit of indeterminate beans and maize for intercropping. Field Crops Research 6: 59-75.

Dechasa Hirpha (2005). Effect of moisture conservation methods and plant density of component crops on performance of sorghum/bean intercropping in Meiso district, west Hararghe. M.Sc. Thesis, Haramaya University, Ethiopia.

Echarte L., Luque S., Andrade F.H., Sadras V.O., Cirilo A., Otequi M.E., Vega C.R.C. (2000). Response of maize kernel number to plant density in Argentinean hybrids released between 1965 and 1993. Field Crop Research 68: 1-8.

Egbe, O.M. (2010). Effects of plant density of intercropped soybean with tall sorghum on competitive ability of soybean and economic yield at Otobi, Benue State, Nigeria. Journal of Cereals and Oilseeds 1(1): 1-10.

Ghosh, P.K. (2004). Growth, yield, competition and economics of groundnut/cereal fodder intercropping systems in the semi-arid tropics of India. Field Crops Research, 88:227-237.

Haffanaghel, H. P., 1961. Agriculture in Ethiopia. FAO, Rome.

Jones, R.J., Simmons, S.R. (1986). Effect of altered sourcesink ratio on growth of maize kernels. Crop Science 23 : 129-134.

Karikari, S.K., Chaba, O., Molosiwa, B. (1999). Effects of Intercropping Bambara Groundnut on Pearl millet, Sorghum and Maize in Botswana. African Crop Science Journal 7(2): 143-152.

Khan, Z.R., Midega, C.A.O., Hassnalli, A., Pickett, J.A., Wadhams, L.J. (2007). Assessment of different legumes for control of striga hermonthica in maize and sorghum. Crop Science 47: 730-736.

Kipkemoi, P.L, Wasike, V.W., Oro, P.A., Riungu, T.C., Bor, P.K., Rogocho, L.M. (2003). Effects of Intercropping Pattern on Soybean and Maize Yield in Central Rift Valley of Kenya. Kenya Agricultural research Institute, Nairobi, Kenya

Lakhani, D. A. (1976). A Crop Physiological Study of Mixture of Sunflower and Fodder Radish. PhD. Thesis, University of Reading.

Landon, J. R. (1991). Tropical soil manual: a handbook for soil survey and agricultural land evaluation in the tropics and sub tropics. Longman Scientific and Technical, Longman Group, UK Ltd.

Lemcoff, J.H., Loomis, R.S. (1986). Nitrogen influences on yield determination in maize. Crop Science 26: 10171022.

Luiz, B.M., Robert W.W. (2003). Effects of plant population and nitrogen fertilizer on yield and efficiencyof maizebean intercropping. Pesq agropec bras Brasília 38(11): 1257-1264.

Mudita, I.I., Chiduza, C., Richardson, S.J., Murungu, K.J. (2008). Performance of maize (Zea mays L.) and soybean ( Glycine $\max (\mathrm{L})$ Merrill) cultivars of varying Growth habit in intercrop in Semi-humid of Zimbabwe. Journal of Agronomy 7(3): 229-236.

Muoneke, C.O.,Ogwuche, M.O., Kalu, B.A. (2007). Effect of maize planting Density on the performance of 


\section{Teshome Gutu et al.,}

maize/soybean intercropping system in a guinea savanna agroecosystem. Afrcan Journal of Agricultural Research 2: $667-677$

O'leary, N., Smith, M. E. (2004). Uncovering corn adaptation to intercrop with bean by selecting for system yield in intercropped Environment. Journal of Sustainable Agriculture 24: 109-121.

Ofri, F. and Stern, W.R., 1987. Cereal-legume intercropping systems. Advances in Agronomy 41: 41-89.

Olsen, S. R., Cole, C.V., Watanable, F.S., Dean, L.A. (1954). Estimation of available phosphorous in soils by Extraction with Sodium Bicarbonate. U.S. Department of Agriculture, 939: 1-19.

Onwueme, I.C., Sinha, T.D. (1991). Field Crop Production in Tropical Africa. CTA. Wageningen, The Netherlands.

Page,A.L. (1982). Methods of soil analysis part two. Chemical and microbilogical properties. American Society of Agronomy 3:128-133.

Raji, J.A. (2007). Intercropping soybean and maize in a derived savanna ecology. African Journal of Biotechnology 6(16): 1885-1887

Rao, M.R., Willey, R.W. (1980). Evaluation of Yield Stability in Intercropping Studies on Sorghum/ Pigeon pea. Experimental Agriculture 16(2):105-116.

Russelle, M.P., Hargrove, W.L. (1989). Cropping systems: Ecology and Management. Pp. 277-317.

Salvador, R.J., Pearce, R.B. (1995). Proposed standard system of nomenclature for maize grain filling events. Maydica 40: 141-146

SAS (Statistical Analysis System) (2002). SAS User Guide, Statistics SAS Inc. Cary. North Carolina, USA.

Shehu, Y., Alhassan, W. S., Pal, U. R., Phillips, C. J. C. (1999). The Effect of intercropping Lablab purpureus L. with sorghum on yield and chemical composition of fodder. Journal of Agronomy and Crop Science 183: 7379.
Sci. Technol. Arts Res. J., Oct-Dec 2015, 4(4): 31-39

Singh, C. (1983). Modern Techniques of Raising Filed Crops. Oxford and IBH publishing Co. Pvt. Ltd., New Delhi, pp: 301-302.

Sisay Tekle (2004). Effect of planting pattern and proportion of green gram (Vigna radiate $(L)$ wilczec) on productivity of sorghum/green gram intercropping system in Kewet wereda. Amhara Region. MSc. Thesis, Alemaya University, Ethioipia. 109p

Tamado Tana and Eshetu Mulatu (2000). Evaluation of sorghum, maize and common bean intercropping systems in Eastern Hararghe. Ethiopian Journal of Agricultural Science 17(2):33-46.

Tilahun Tadesse (2002). Effects of Planting Arrangement of Component Crops on Productivity of Maize/Faba Bean Intercropping Systems. MSc. Thesis, Haramaya ,University, Ethiopia

Tolera Abera (2003). Effects of Nitrogen, Phosphorus and Farm Yard Manure and Population of Climbing Bean on the Performance of Maize (Zea mays L.)/Climbing Bean (Phaseolus vulgaris L.) Intercropping Systems in Alfisols of Bako. MSc thesis ,Haramaya University, Ethiopia.

Vandermeer, J.H., 1989. The Ecology of Intercropping Cambrge university press. Cambridge. UK.

Walkley, A., Black, I.A. (1934). An examination of digestion of degrjareff method for determining soil organic matter and proposed modification of the chromic acid titration method. Soil Science 37:29-38

Yesuf Mohammed (2003). Effects of Planting Arrangement and Population Densities of Haricot Bean on Productivity of Sorghum/Haricot Bean Additive Mixture. M.Sc. Thesis. Haramaya University, Ethiopia.

Zerihun Abebe (2011). System Productivity as Influenced by Integrated Organic and Inorganic FertilizerApplication in Maize (zea mays I.) Intercropped with Soybean (glycine max I. merrill) Varieties at Bako, Western Ethiopia. M.Sc. Thesis. Haramaya University, Ethiopia. 